\title{
Toplinski otpor goveđe kože i kompozitnih laminata za profesionalnu obuću
}

\author{
Zenun Skenderi, Snježana Firšt Rogale, Jadranka Akalović, Emilija Zdraveva \\ Sveučilište u Zagrebu Tekstilno-tehnološki fakultet
}

\section{Sažetak:}

Istražen je toplinski otpor različitih goveđih koža (boks, velur, hidrofobirana napa, podstavna obućarska napa) i kompozitnih laminata (2-slojni laminat za izradu jezika obuće, 2-slojni laminat za izradu sara, 4-slojni laminat sa membranom za podstavu i 3-slojni laminat za podstavu) namijenjenih za izradu profesionalne obuće. Toplinski otpor je određen na uređaju PEMETEST. Toplinski otpor koža debljine 1,16 do 2,37 mm kreće se u granicama od 0,0813 do $0,0989 \mathrm{~m}^{2} \mathrm{C} \mathrm{W}^{-1}$. Toplinski otpor tekstilnih laminata, u prosjeku je niži od otpora prolazu topline koža, i iznosi 0,0701 do $0,0918 \mathrm{~m}^{2} \mathrm{C} \mathrm{W}^{-1}$.

\section{Ključne riječi:}

goveđa koža, kompozitni laminat, profesionalna obuća, toplinski otpor, permetest

\section{Uvod}

Funkcija obuće je da osigura udobnost osobe i zaštitu stopala od grubih uvjeta okoline kao što su hladnoća i/ili vlažni uvjeti [1]. Namjena svake vrste obuće određena je funkcionalnim i specifičnim svojstvima kože i drugih materijala iz kojih je izrađena [2]. Tako npr. gornjište radne obuće se obično izrađuje iz goveđe hidrofobirane kvalitetne kože debljine 1,8 do 2 $\mathrm{mm}$, podstava iz tekstilnih materijala koji su otporni na habanje uz dobro upijanje znoja i brzo sušenje, potplat iz brizganog poliuretana, kapica čelična (na zahtjev) te tabanica koja može biti i neprobojna. Nadalje, kada se radi o vojnoj obući, onda se gornjište obično izrađuje od visokokvalitetne goveđe hidrofobirane kože debljine 2,1 do $2,3 \mathrm{~mm}$, podstava od vodonepropusne membrane (materijali Sympatex®, GORE-TEX®), potplat iz gume i poliuretana otporni na ulje, benzin i antistatičan, termokapicu i neprobojnu tabanicu [3].

Tehnološki proces obrade sirove kože i dobivanja gotove provodi se kroz niz mehaničkih i kemijskih tehnoloških operacija od pripremnih preko štavljenja do dovršnih. Mehaničke i kemijske operacije pripremnih radova obrade kože važne su za osiguranje optimalne difuzija sredstava za obradu kože u narednim tehnološkim operacijama štavljenja, bojanja, mašćenja i dr. [4]. Pored toga enzimatska obrada u pripremnim radovima utječe i na svojstva propusnosti (vodene pare, zraka i topline).

Fizikalno-mehanička svojstva gotovih koža ovise ne samo o svojstvima njihovih vlakana, već i o međusobnom položaju i građi, tj. mikrostrukturi koža. Mikrostruktura koža ovisi o svojstvu sirovih koža pojedinih topografskih dijelova i o procesu prerade. Osnovni pokazatelji mikrostrukture koža su: pravilnost spleta vlakana, kut ispreplitanja, gustoća spleta, savijenost vlakana, stupanj razdijeljenosti i debljina vlakana. Mikrostruktura koža određuje pored ostalih i fizikalno svojstvo propusnosti topline i vodene pare.

Termofiziološka svojstva materijala (toplinski otpor i otpor prolazu vodene pare) za izradu obuće u posljednje su vrijeme sve više predmet istraživanja u svijetu [5]. Toplinska vodljivost naročito je važno kod koža za izradu obuće (donjih i gornjih), a poželjna je njena što manja vrijednost. Toplinska vodljivost ovisi o svojstvima kožnog tkiva. Rahlije građeni dijelovi kože imaju veći toplinski otpor od gušće građenih dijelova kože. Povećani sadržaj masnoća i vlage u koži povisuje toplinsku vodljivost. Količina i vrsta masnoće imaju veliki utjecaj na toplinsku vodljivost. Rezultati ispitivanja toplinskog otpora i otpora prolazu vodene pare različito obrađenih goveđih koža, pokazali su da obrada kože značajno utječe na svojstva propusnosti topline i osobito vodene pare, pa je potrebna sustavna evaluacija prolaza topline i vodene pare materijala za izradu obuće. Kromno štavljene kože imaju najveću toplinsku vodljivost i najniže vrijednosti toplinskog otpora. Biljno štavljene kože imaju najveću toplinsku absorptivnost koja je povezana sa znatnom količinom štavnih i neštavnih tvari prisutnih u strukturi [6]. Različite obrade sirovih koža rezultiraju različitim funkcionalnim svojstvima gotovih koža, pa tako i na svojstv propusnosti topline i/ili vodene pare. Tako, Çolak i sur. [7] nalaze da kože debljine 1,3 do 1,4 mm, štavljene različitim štavama imaju toplinski otpor u granicama od 0,0255 do 0,0275 $\mathrm{m} 2{ }^{\circ} \mathrm{C} / \mathrm{W}$, i kod toga se pokazalo da su dobivene razlike u otporu prolaza topline do $7,8 \%$.

Nadalje, Hes i sur. [8] istraživali su toplinsku otpornost goveđih koža različitih debljina $(0,54$ do $1,63 \mathrm{~mm})$ i PA pletiva naslojenih PUR (umjetnih koža) u mokrom stanju.

Uobičajeno, cipele imaju funkciju održavanja temperature stopala i udobnosti unutar širokog temperaturnog područja od -5 do $+25^{\circ} \mathrm{C}$ pod normalnim aktivnostima $\mathrm{i}$ vlastitom toplinskom reakcijom tijela i preraspodjele topline. Većina običnih cipela i radne obuće imaju ukupni toplinski otpor (izolaciju) oko i iznad $0,20 \mathrm{~m} 2{ }^{\circ} \mathrm{C} / \mathrm{W}$ [9]. Rezultati toplinskog otpora određene obuće ovisi i o uvjetima okoline (temperature, vlažnosti), brzini strujanja zraka (vjetru), radijaciji te o stupnju aktivnosti osobe [10].

Toplinski otpor obuće za različita temperaturna područja okoline za nisku aktivnost čovjeka od oko $10 \mathrm{~W} / \mathrm{m} 2$ prikazan je u tab. 1 [1].

Tab. 1 Preporučene vrijednosti toplinskog otpora obuće kod nižih aktivnosti (oko $10 \mathrm{w} / \mathrm{m}^{2}$ ).

\begin{tabular}{|l|l|}
\hline Temperatura okoline $\left({ }^{\circ} \mathbf{C}\right)$ & $\begin{array}{l}\text { Toplinski otpor obuće } \text { Rct }\left(\mathbf{m}^{2}\right. \\
\left.{ }^{\circ} \mathbf{C} / \mathbf{W}\right)\end{array}$ \\
\hline+15 to +5 & $0,20 \leq$ Rct $<0,25$ \\
\hline+5 to -5 & $0,25 \leq$ Rct $<0,30$ \\
\hline-5 to -15 & $0,30 \leq$ Rct $<0,37$ \\
\hline$<-25$ & $0,45 \leq$ Rct \\
\hline
\end{tabular}

Tekstilni kompozitni laminati koji se koriste za izradu obuće, imaju jače izražena fizikalno-mehanička, toplinska i ergonomijska svojstva u ovisnosti o dijelu obuće za koji je namijenjen. Za podstavu isti moraju imati veću čvrstoću i dobru toplinsku otpornost. Malo je publiciranih radova koji obrađuju navedena specifična svojstva pojedinih dijelova obuće. Utjecaj tri tipa podstavnih kompozitnih laminata za izradu zaštitne obuće (1-slojni, 2slojni i 3-slojni) različitog sirovinskog sastava na subjektivno ocjenjenu udobnost (45 ispitanika) bavila se Irzmańska [11].

Precizniji rezultati ukupne ocjene udobnosti obuće svakako se dobivaju kada bi se uz objektivna mjerenja, vršila i subjektivna mjerenja na ispitanicima [12].

\section{Eksperimentalni dio}

\subsection{Izbor materijala}

Jedan dio uzoraka za ovaj rad, uzorci koža $A$ do $E$ (tab. 1) je isti kao u radu Akalović i sur. [5]. u kome je određen samo otpor prolazu vodene pare. Uzorci A, B, C, D, E su različiti artikli gotove kože (boks, velur, napa) dobiveni $u$ industrijskim uvjetima obradom sirove goveđe kože srednje težinske kategorije $(30 / 40 \mathrm{~kg} / \mathrm{kom})$.

$\mathrm{U}$ ovom radu je određena debljina te toplinski otpor na navedenim uzorcima koža. Drugi dio uzoraka korištenih u ovom radu su 
uzorci kompozitnih laminata (oznaka F,G, H i I) koji se koriste za izradu različitih dijelova profesionalne obuće (za podstavu, saru i jezik). Oznake i opis uzoraka dani su u tab. 2.

Tab. 2 Oznake i opis uzoraka

\begin{tabular}{|c|c|c|}
\hline $\begin{array}{l}\text { Oznaka } \\
\text { uzoraka }\end{array}$ & Naziv uzorka & Opis uzorarka \\
\hline A & Goveđi boks & $\begin{array}{l}\text { Hidrofobiran, kromno } \\
\text { štavljen } \\
\text { Lagano vegetabilno } \\
\text { doštavljen } \\
\text { Lice dovršeno PU } \\
\text { dogotovom }\end{array}$ \\
\hline $\mathrm{B}$ & Goveđi velur & $\begin{array}{l}\text { Hidrofobiran, kromno } \\
\text { štavljen }\end{array}$ \\
\hline C & Goveđi obućarski velur & $\begin{array}{l}\text { Hidrofobiran, kromno } \\
\text { štavljen }\end{array}$ \\
\hline D & Goveđa hidrofobirana napa & $\begin{array}{l}\text { Kromno štavljena } \\
\text { Blago vegetabilno } \\
\text { doštavljena } \\
\text { PU dogotova lica }\end{array}$ \\
\hline$E$ & $\begin{array}{l}\text { Obučarska napa kao } \\
\text { podstavna koža }\end{array}$ & Kromno štavljena \\
\hline $\mathrm{F}$ & $\begin{array}{l}\text { Dvoslojni tekstilni laminat za } \\
\text { izradu jezika }\end{array}$ & $\begin{array}{l}\text { Lice tkanina PAs } \\
\text { adhezivom, } \\
\text { Naličje tkanina PET (ili } \\
\text { PET/Viskoza) } \\
\text { Površinska masa: } 435 \text { (+/- } \\
10 \% \text { g/m² }\end{array}$ \\
\hline G & $\begin{array}{l}\text { Doslojni tekstilni laminat za } \\
\text { sare }\end{array}$ & $\begin{array}{l}\text { Lice: tkanina PA/PUR } \\
\text { adheziv } \\
\text { Naličje: tkanina: pamuk } \\
100 \% \\
\text { Površinska masa: } 480(+/- \\
10 \%) \text { g/m² }\end{array}$ \\
\hline $\mathrm{H}$ & $\begin{array}{l}\text { Četveroslojni laminat, } \\
\text { membrana, za izradu } \\
\text { podstavnih dijelova obuće } \\
\text { (podstava). }\end{array}$ & $\begin{array}{l}\text { 1. sloj: pletivo PA } 80- \\
\text { 85\% i PET } 15-20 \% \text { PES } \\
\text { 2. sloj: PET } 100 \% \\
\text { 3. sloj: PTFE membrana } \\
\text { 4. sloj: pletivo PA } 100 \% \text {. } \\
\text { Površinska masa: } 320 \text { do } \\
380 \mathrm{~g} / \mathrm{m}^{2}\end{array}$ \\
\hline I & $\begin{array}{l}\text { Troslojni laminat za izradu } \\
\text { podstavnih dijelova obuće } \\
\text { (podstava) }\end{array}$ & $\begin{array}{l}\text { 1. sloj: pletivo PA } 80 \text { - } \\
\text { 85\%; PET } 15 \text { - } 20 \% \\
\text { 2. sloj: membrana PTFE } \\
\text { 100\% } \\
\text { 3. sloj: pletivo PA } 100 \% \\
\text { Površinska masa: } 210 \text { do } \\
250 \mathrm{~g} / \mathrm{m}^{2}\end{array}$ \\
\hline
\end{tabular}

\subsection{Metode ispitivanja}

Mjerenje debljine kože je izvršeno na uređaju HESS prema norm HRN EN ISO 2589:2016 [13]. Mjerenje debljine uzoraka tekstilnih kompozitnih laminata izvršeno je na istom uređaju HESS thickness meter prema normi ISO 5084:1996 [14]. Veličina uzoraka je bila 31 x $31 \mathrm{~cm}$. Svaki uzorak ima po tri mjerne epruvete. Tako npr. uzorak A ima 3 mjerne epruvete oznake A1, A2 i A3, i tako redom do I. Na svakoj mjernoj epruveti određenog uzorka izvršeno je po 5 mjerenja debljine, određena st. devijacija i područje vrijednosti debljine uz statističku pouzdanost od $95 \%$. Uvjeti okoline kod mjerenja debljine bili su: $\mathrm{t}=20 \pm 2 \mathrm{C}$ i RH: $65 \pm 5 \%$.

Kod određivanja otpora prolazu topline na PERMETEST-u izvršena su po 2 mjerenje po mjernoj epruveti svakog uzorka, 1 na licu i 1 na naličju. PERMETEST uređaj [15] mjeri toplinski otpor na nedestruktuvan način, a koristi se prvenstveno za tekstilne materijale, tekstilne kompozite kožu debljine 0,1 do $7 \mathrm{~mm}$ za područje u rasponu od 0,02 do $1 \mathrm{~m}^{2} \mathrm{C} / \mathrm{W}$. Uvjeti okoline kod mjerenja na PERMETESTU bili su, temperatura $=21-$ $24 \mathrm{C}$ i relativna vlažnost: 46 do $52 \%$.
Uređaj PERMETEST mjeri toplinski otpor po jednakom principu kao i uređaj Vruća ploča prema normi ISO 11092 [16]. Toplinski otpor uzorka Rct $\left(\mathrm{m}^{2} \mathrm{C} / \mathrm{W}\right)$ određen prema slijedećoj jednadžbi:

$$
R_{c t}=\frac{\left(T_{s}-T_{a}\right) A}{Q}-R_{c t o}
$$

gdje je $T_{s}$ temperetura mjerne površine uređaja $(C), T_{a}$ temperatura okoline, A površina mjerne površine uređaja, $Q$ energija u vremenu potrebna za održavanje temperature mjernog elementa obično na $35 \mathrm{C}(\mathrm{J} / \mathrm{s}=\mathrm{W}) . \mathrm{R}_{\text {cto }}$ toplinski otpor uređaja (mjerne ploče).

\section{Rezultati i diskusija}

U tablicama 3 i 4 prikazani su rezultati mjerenje debljine koža odnosno kompozitnih laminata, dok su u tabl. 5 i 6 prikazani rezultat mjerenja otpora prolazu topline koža odnosno kompozitnih laminata određeni na PERMETESTU. Na slici 1 prikazani su rezultati mjerenja debljine svih uzoraka. Na sl. 2 prikazani su rezultati mjerenja toplinskog otpora koža i kompozitnih materijala koji se koriste u industriji obuće. Slika 3 pokazuje postotnu razliku otpora prolazu topline koža i kompozitnih laminata lica i naličja za izradu profesionalne obuće. Prikaz otpora prolazu topline (od najmanjeg do najvišeg) i debljine kože odnosno debljine kompozitnih laminata prikazani su na slikama 4 i 5.

Tab. 3 Rezultati mjerenja debljine uzoraka koža za izradu profesionalne obuću

\begin{tabular}{|c|c|c|c|}
\hline $\begin{array}{c}\text { Oznaka i opis } \\
\text { uzorka }\end{array}$ & $\begin{array}{l}\text { Srednja vrij. } \\
(\mathrm{mm})\end{array}$ & Stand. dev. $(\mathrm{mm})$ & $\begin{array}{c}\text { Područje (stat. } \\
\text { pouzd. } 95 \%) \\
(\mathrm{mm})\end{array}$ \\
\hline $\mathrm{A} 1$ & 2,35 & 0,037 & $2,35 \pm 0,07$ \\
\hline $\mathrm{A} 2$ & 2,37 & 0,036 & $2,37 \pm 0,07$ \\
\hline A3 & 2,38 & 0,044 & $2,38 \pm 0,09$ \\
\hline Sred. vr. (mm) & 2,37 & & \\
\hline Stand. dev. $(\mathrm{mm})$ & 0,02 & & \\
\hline CV $(\%)$ & 0,84 & & \\
\hline B1 & 1,13 & 0,023 & $1,13 \pm 0,04$ \\
\hline B2 & 1,17 & 0,005 & $1,17 \pm 0,01$ \\
\hline B3 & 1,19 & 0,015 & $1,19 \pm 0,03$ \\
\hline Sred. vr. (mm) & 1,16 & & \\
\hline Stand. dev. $(\mathrm{mm})$ & 0,03 & & \\
\hline CV (\%) & 2,59 & & \\
\hline $\mathrm{C} 1$ & 2,35 & 0,060 & $2,35 \pm 0,12$ \\
\hline $\mathrm{C} 2$ & 2,32 & 0,059 & $2,32 \pm 0,12$ \\
\hline $\mathrm{C} 3$ & 2,34 & 0,031 & $2,34 \pm 0,06$ \\
\hline Sred. vr. (mm) & 2,34 & & \\
\hline Stand. dev. $(\mathrm{mm})$ & 0,01 & & \\
\hline CV $(\%)$ & 0,43 & & \\
\hline D1 & 2,01 & 0,063 & $2,01 \pm 0,12$ \\
\hline D2 & 1,96 & 0,025 & $1,96 \pm 0,05$ \\
\hline D3 & 1,97 & 0,049 & $1,97 \pm 0,10$ \\
\hline Sred. vr. (mm) & 1,98 & & \\
\hline Stand. dev. $(\mathrm{mm})$ & 0,03 & & \\
\hline $\mathrm{CV}(\%)$ & 1,51 & & \\
\hline E1 & 1,18 & 0,050 & $1,18 \pm 0,10$ \\
\hline E2 & 1,18 & 0,055 & $1,18 \pm 0,11$ \\
\hline E3 & 1,16 & 0,033 & $1,16 \pm 0,06$ \\
\hline Sred. vr. (mm) & 1,17 & & \\
\hline Stand. dev. $(\mathrm{mm})$ & 0,01 & & \\
\hline $\mathrm{CV}(\%)$ & 0,85 & & \\
\hline
\end{tabular}


Tab. 4 Rezultati mjerenja debljine uzoraka kompozitnih laminata za izradu profesionalne obuće

\begin{tabular}{|c|c|c|c|}
\hline $\begin{array}{l}\text { Oznaka i opis } \\
\text { uzorka }\end{array}$ & $\begin{array}{l}\text { Srednja vrij. } \\
(\mathrm{mm})\end{array}$ & $\begin{array}{l}\text { Stand. dev. } \\
(\mathrm{mm})\end{array}$ & $\begin{array}{c}\text { Područje, stat. } \\
\text { pouzd. } 95 \% \\
(\mathrm{~mm})\end{array}$ \\
\hline $\mathrm{F} 1$ & 1,44 & 0,014 & $1,44 \pm 0,03$ \\
\hline $\mathrm{F} 2$ & 1,41 & 0,008 & $1,41 \pm 0,02$ \\
\hline F3 & 1,43 & 0,033 & $1,43 \pm 0,06$ \\
\hline Sred. vr. (mm) & 1.42 & & \\
\hline Stand. dev. (mm) & 0,02 & & \\
\hline CV (\%) & 1,41 & & \\
\hline $\mathrm{G} 1$ & 0,91 & 0,011 & $0,91 \pm 0,02$ \\
\hline G2 & 0,90 & 0,010 & $0,90 \pm 0,02$ \\
\hline G3 & 0,91 & 0,007 & $0,91 \pm 0,01$ \\
\hline Sred. vr. (mm) & 0,91 & & \\
\hline Stand. dev. $(\mathrm{mm})$ & 0,01 & & \\
\hline CV $(\%)$ & 1,10 & & \\
\hline $\mathrm{H} 1$ & 1,55 & 0,017 & $1,55 \pm 0,03$ \\
\hline $\mathrm{H} 2$ & 1,57 & 0,014 & $1,57 \pm 0,03$ \\
\hline $\mathrm{H} 3$ & 1,59 & 0,017 & $1,59 \pm 0,03$ \\
\hline Sred. vr. (mm) & 1,57 & & \\
\hline Stand. dev. $(\mathrm{mm})$ & 0,02 & & \\
\hline CV $(\%)$ & 1,10 & & \\
\hline 11 & 0,74 & 0,000 & $0,74 \pm 0,00$ \\
\hline 12 & 0,74 & 0,000 & $0,74 \pm 0,00$ \\
\hline 13 & 0,72 & 0,000 & $0,72 \pm 0,00$ \\
\hline Sred. vr. (mm) & 0,73 & & \\
\hline Stand. dev. $(\mathrm{mm})$ & 0,01 & & \\
\hline CV $(\%)$ & 1,37 & & \\
\hline
\end{tabular}

Debljina koža i kompozitnih laminata

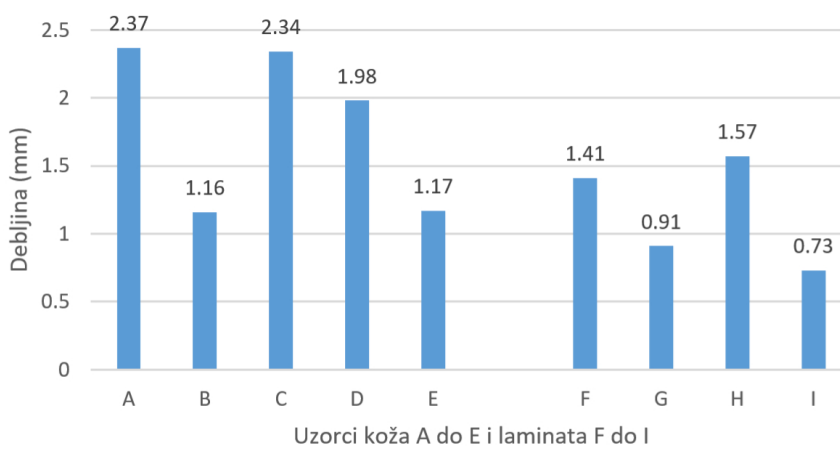

SI. 1 Debljina koża i tekstilnih kompozitnih laminata za izradu profesionalne obuće

Debljina koža u ovisnosti o namjeni, kreće se u granicama od $1,16 \mathrm{~mm}$ (goveđi velur, uzorak B) do 2,37 mm (goveđi boks, uzorka A) (tab. 3 , sl. 1). Koeficijent varijacije srednjih vrijednosti debljine kože pojedinih uzoraka kreće se u granicama od 0,84 \% (goveđi boks, uzorak A) do 2,59 $\%$ (goveđi velur, uzorak $B$ ). Može se kazati da su varijacije debljine kože, kako kod mjernih epruvata tako i kod uzoraka male tj. kože su izraženo jednolične debljine.

Debljina kompozitnih laminata koji se koriste za izradu profesionalne obuće kreće se u granicama od 0,73 $\mathrm{mm}$ (3-slojni tekstiln laminat za postavu, uzorak I) do $1,57 \mathrm{~mm}$ (4-slojni tekstilni laminat sa membranom za podstavu, uzorak $\mathrm{H}$ ), a što je prikazano u tab. 4 i na sl. 1. Koeficijent varijacije debljine srednjih vrijednosti uzoraka je u granicama od 1,41 mm (2-slojni laminat za izradu jezika, uzorak F) do $1,10 \mathrm{~mm}$ (2-slojn tekstilni laminat za sare i 2-slojni tekstilni laminat sa membranom za podstavu, uzorci G i H). Niske vrijednosti koeficijenta varijacije kompozitnih laminata pokazuju dobru kvalitetu pojedinih komponenti kao i postupka laminiranja.

Toplinski otpor koža i kompozitnih laminata ispitan je na dva načina, prvi s licem prema mjernoj ploči i drugi s naličjem prema mjernoj ploči (tab. 5 i 6 , sl. 3). Maksimalna vrijednost koeficijenta varijacije otpora prolazu topline lica i naličja je 5,5 \% (2-slojni tekstilni laminat za izradu jezika, uzorak F). Razmjerno malo odstupanje otpora prolazu topline lica i naličja koža i kompozitnih laminata je posljedica uobičajenih odstupanja debljine koža, procesa obrade, posebno u dovršnim obradama kožnog tkiva i prirodnog lica kože, odnosno različitih debljina pojedinih elementa kompozita i procesa laminiranja. Daljnja analiza i diskusija uzet će samo rezultate otpora prolazu s polaganjem lica uzoraka na mjerni element.

Toplinski otpor različit je za ispitane kože, i kreće se u granicama od 0,0813 $\mathrm{m}^{2} \mathrm{C} / \mathrm{W}$ goveđi boks, uzorak A) do 0,0989 $\mathrm{m}^{2} \mathrm{C} / \mathrm{W}$ (obućarska napa kao podstavna koža, uzorak E) (tab. 5, sl. 2 i 4). Najveća razlika otpora prolazu topline koža iznosi 21,6 \%. Debljina je jedan od parametara od kojih ovisi toplinski otpor. Utjecaj debljine je uočen kod uzoraka C i D. Naime, povećanje debljine kože sa $1,98 \mathrm{~mm}$ (goveđa hidrofobirana napa, uzorak D) na 2,34 mm (goveđi obućarski velur, uzorak C) dalo je povećanje otpora prolazu topline za 18,2 \% (tab. 3). Uzorak C je kromno štavljen, a izmjerena je veća vrijednost otpora u odnosu na uzorak D koji je štavljen kromno i blago vegetabilno doštavljen. Pored navedenog utjecaja debljine koža, razlika u mikrostrukturi uzorka C i D također je mogla utjecati na veću vrijednost otpora prolazu topline uzorka $\mathrm{C}$.

Za ostale uzorke je vidljivo, da pored debljine i drugi parametri utječu na razinu otpora prolazu topline koža, što je posebno izraženo kod uzoraka relativno manje debljine $B$ (goveđi velur) i E (obućarska napa kao podstavna koža), čije su debljine znatno manje $(1,1 \mathrm{~mm})$. Debljine uzoraka $B$ i E su gotovo jednakih vrijednosti (uzorak B 1,16 mm; uzorak E 1,17 mm), a izmjereni otpori prolazu topline ne pokazuju tako približno jednake vrijednosti. Uzorak E je kromno štavljena koža i trebao bi imati manje vrijednosti otpora u odnosu na uzorak B koji je štavljen kombiniranom kromnom i vegetabilnom štavom. Veća vrijednost otpora izmjerena na uzorku $\mathrm{E}$ u odnosu na vrijednosti otpora izmjerene na uzorku B (za 5,8 \%) može se povezati sa obradom prirodnog lica kože uzorka E i mikrostrukturom uzorka B. Naravno, utjecajni parametri su najprije struktura kože i postupci njezine obrade i dorade. Za potpuno definiranje razine utjecaja svih parametara koža na toplinski otpor, potrebno je poznavanje svih postupaka obrade i dorade koža sa recepturama, a što će biti obuhvaćeno u narednim istraživanjima.

Toplinski otpor kompozitnih laminata (tab. 6, sl. 2 i 5) kreće se u granicama $0,0701 \mathrm{~m}^{2} \mathrm{C} / \mathrm{W}$ (4-slojni kompozitnih laminata sa membranom za podstavu, uzorak $\mathrm{H}$, lice) do $0,0918 \mathrm{~m}^{2} \mathrm{C} / \mathrm{W}$ (2-slojni tekstilni laminat za sare, uzorak G, lice). Za izradu profesionalne obuće koriste se ratličite vrste kompozitnih laminata a što ovisi o dijelu obuće za koji se laminati koriste i namjeni profesionalne obuće.

Tab. 5 Rezultati mjerenja toplinskog otpora koža za izradu profesionalne obuće određeni na PERMETESTU

\begin{tabular}{|c|c|c|}
\hline \multirow{2}{*}{ Parametri } & \multicolumn{2}{|c|}{ Toplinski otpor $\left(\mathrm{m}^{2} \times{ }^{\circ} \mathrm{C} / \mathrm{W}\right)$} \\
\hline & Lice & Naličje \\
\hline A1 & 0,0810 & 0,0824 \\
\hline A2 & 0,0812 & 0,0826 \\
\hline A3 & 0,0818 & 0,0842 \\
\hline Sr. vrij. $\left(\mathrm{m}^{2}{ }^{\circ} \mathrm{C} / \mathrm{W}\right)$ & 0,0813 & 0,0831 \\
\hline STDEV.S $\left(\mathrm{m}^{2}{ }^{\circ} \mathrm{C} / \mathrm{W}\right)$ & 0,00042 & 0,00099 \\
\hline $\mathrm{CV}(\%)$ & 0,50 & 1,19 \\
\hline B1 & 0,0946 & 0,0944 \\
\hline B2 & 0,0922 & 0,09 \\
\hline B3 & 0,0938 & 0,0901 \\
\hline Sred. vrij. $\left(\mathrm{m}^{2}{ }^{\circ} \mathrm{C} / \mathrm{W}\right)$ & 0,0935 & 0,0915 \\
\hline STDEV.S $\left(\mathrm{m}^{2}{ }^{\circ} \mathrm{C} / \mathrm{W}\right)$ & 0,00122 & 0,00251 \\
\hline $\mathrm{CV}(\%)$ & 1,3 & 2,73 \\
\hline $\mathrm{C} 1$ & 0,0916 & 0,0923 \\
\hline $\mathrm{C} 2$ & 0,0939 & 0,0978 \\
\hline $\mathrm{C} 3$ & 0,0931 & 0,0879 \\
\hline Sred. vrij. $\left(\mathrm{m}^{2}{ }^{\circ} \mathrm{C} / \mathrm{W}\right)$ & 0,0929 & 0,0927 \\
\hline STDEV.S $\left(\mathrm{m}^{2}{ }^{\circ} \mathrm{C} / \mathrm{W}\right)$ & 0,00117 & 0,00496 \\
\hline $\mathrm{CV}(\%)$ & 1,26 & 5,35 \\
\hline $\mathrm{D} 1$ & 0,0831 & 0,0906 \\
\hline D2 & 0,0859 & 0,0846 \\
\hline D3 & 0,0876 & 0,0925 \\
\hline Sred. vrij. $\left(\mathrm{m}^{2}{ }^{\circ} \mathrm{C} / \mathrm{W}\right)$ & 0,0855 & 0,0892 \\
\hline STDEV.S $\left(\mathrm{m}^{2}{ }^{\circ} \mathrm{C} / \mathrm{W}\right)$ & 0,00227 & 0,00412 \\
\hline $\mathrm{CV}(\%)$ & 2,65 & 4,59 \\
\hline $\mathrm{E} 1$ & 0,0985 & 0,0965 \\
\hline E2 & 0,0985 & 0,0959 \\
\hline E3 & 0,0997 & 0,0998 \\
\hline Sred. vrij. $\left(\mathrm{m}^{2}{ }^{\circ} \mathrm{C} / \mathrm{W}\right)$ & 0,0989 & 0,0974 \\
\hline STDEV.S $\left(\mathrm{m}^{2}{ }^{\circ} \mathrm{C} / \mathrm{W}\right)$ & 0,00069 & 0,0021 \\
\hline $\mathrm{CV}(\%)$ & 0,70 & 2,16 \\
\hline
\end{tabular}


Tab. 6 Rezultati mjerenja toplinskog otpora kompozitnih laminata za izradu profesionalne obuće određeni na PERMETESTU

\begin{tabular}{|c|c|c|}
\hline \multirow{2}{*}{ Parametri } & \multicolumn{2}{|c|}{ Toplinski otpor $\left(\mathbf{m}^{\mathbf{2} \times}{ }^{\circ} \mathbf{C} / \mathbf{W}\right)$} \\
\cline { 2 - 3 } & Lice & Naličje \\
\hline $\mathrm{F} 1$ & 0,0742 & 0,0679 \\
\hline $\mathrm{F} 2$ & 0,074 & 0,0718 \\
\hline F3 & 0,0735 & 0,0698 \\
\hline Sr. vrij. $\left(\mathrm{m}^{2}{ }^{\circ} \mathrm{C} / \mathrm{W}\right)$ & $\mathbf{0 , 0 7 3 9}$ & $\mathbf{0 , 0 6 9 8}$ \\
\hline STDEV.S $\left(\mathrm{m}^{2}{ }^{\circ} \mathrm{C} / \mathrm{W}\right)$ & 0,00036 & 0,00195 \\
\hline $\mathrm{CV}(\%)$ & 0,49 & 2,79 \\
\hline $\mathrm{G} 1$ & 0,0914 & 0,0912 \\
\hline $\mathrm{G} 2$ & 0,0927 & 0,0896 \\
\hline $\mathrm{G} 3$ & 0,0914 & 0,0885 \\
\hline Sred. vrij. $\left(\mathrm{m}^{2}{ }^{\circ} \mathrm{C} / \mathrm{W}\right)$ & $\mathbf{0 , 0 9 1 8}$ & $\mathbf{0 , 0 8 9 7 7}$ \\
\hline STDEV.S $\left(\mathrm{m}^{2}{ }^{\circ} \mathrm{C} / \mathrm{W}\right)$ & 0,00075 & 0,00136 \\
\hline $\mathrm{CV}(\%)$ & 0,82 & 1,51 \\
\hline $\mathrm{H} 1$ & 0,0706 & 0,0689 \\
\hline $\mathrm{H} 2$ & 0,0711 & 0,0706 \\
\hline $\mathrm{H} 3$ & 0,0686 & 0,0698 \\
\hline Sred. vrij. $\left(\mathrm{m}^{2} \mathrm{C} \mathrm{W}^{-1}\right)$ & $\mathbf{0 , 0 7 0 1}$ & $\mathbf{0 , 0 6 9 8}$ \\
\hline STDEV.S $\left(\mathrm{m}^{2} \mathrm{C} \mathrm{W}^{-1}\right)$ & 0,00132 & 0,00085 \\
\hline $\mathrm{CV}(\%)$ & 1,88 & 1,21 \\
\hline $\mathrm{I}$ & 0,0909 & 0,0916 \\
\hline $\mathrm{I}$ & 0,0895 & 0,0899 \\
\hline $\mathrm{I} 3$ & 0,091 & 0,0915 \\
\hline Sred. vrij. $\left(\mathrm{m}^{2}{ }^{\circ} \mathrm{C} / \mathrm{W}\right)$ & $\mathbf{0 , 0 9 0 5}$ & $\mathbf{0 , 0 9 1}$ \\
\hline STDEV.S $\left(\mathrm{m}^{2}{ }^{\circ} \mathrm{C} / \mathrm{W}\right)$ & 0,00084 & 0,00095 \\
\hline $\mathrm{CV}(\%)$ & 0,93 & 1,05 \\
\hline & & \\
\hline
\end{tabular}

Toplinski otpor (Rct) koža i kompozitnih laminata

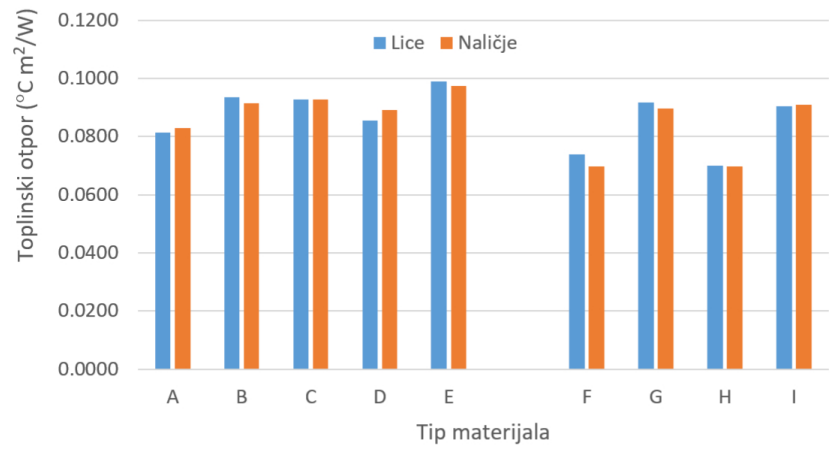

SI. 2 Toplinski otpor (Rct) koža (lijevo, A do E) i kompozitnih laminata (desno, F do I) za izradu profesionalne obuće

Razlika toplinskog otpora (Rct) lica i naličja

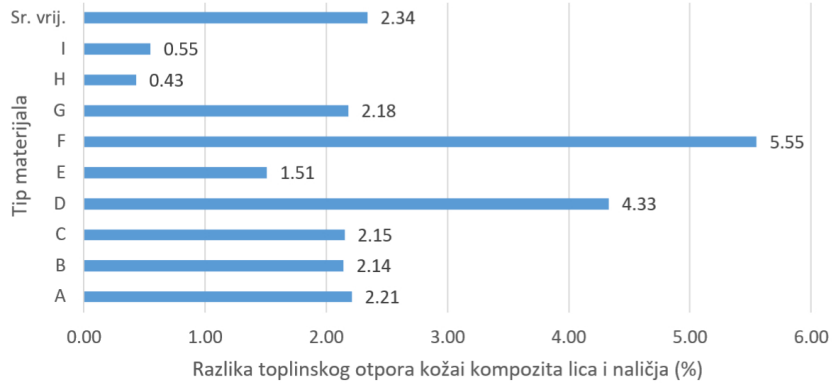

SI. 3 Postotna razlika toplinskog otpora (Rct) koža i kompozitnih laminata lica i naličja za izradu profesionalne obuće

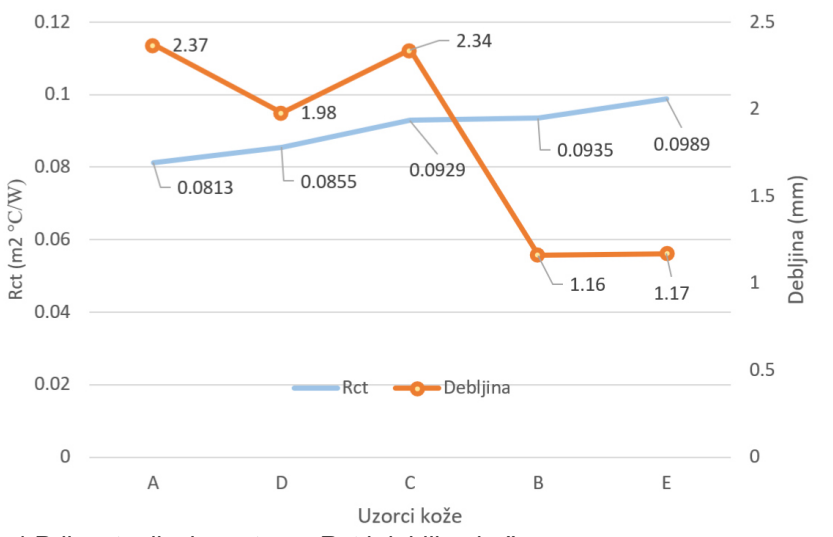

SI. 4 Prikaz toplinskog otpora Rct i debljine kože

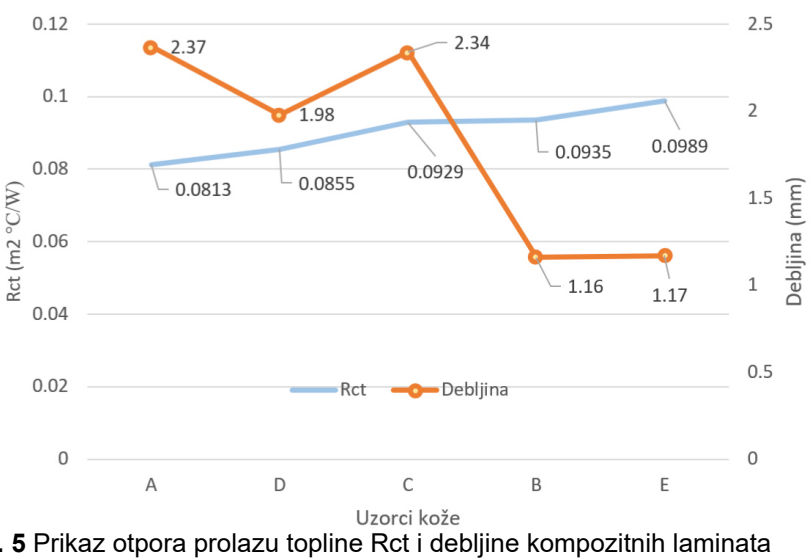

\section{Zaključak}

Temeljem dobivenih rezultata može se zaključiti:

a) Debljina koža za izradu profesionalne obuće kreće se u granicama od 1,16 mm; varijacije debljine koža su izraženo male.

b) Debljina kompozitnih laminata koji se koriste za izradu profesionalne obuće kreće se u granicama od $0,73 \mathrm{~mm}$ do $1,57 \mathrm{~mm}$; koeficijent varijacije debljine srednjih vrijednosti uzoraka je u granicama od $1,41 \mathrm{~mm}$ do $1,10 \mathrm{~mm}$; niske vrijednosti koeficijenta varijacije kompozitnih laminata pokazuju dobru kvalitetu pojedinih komponenti kao i postupka laminiranja.

c) Maksimalna vrijednost koeficijenta varijacije toplinskog otpora lica i naličja je 5,5 \%; Razmjerno malo odstupanje toplinskog otpora lica naličja koža i kompozitnih laminata je posljedica uobičajenih odstupanja debljine koža, procesa obrade i dorade koža, odnosno različitih debljina pojedinih elementa kompozitnih laminata i procesa laminiranja.

d) Toplinski otpor različit je za ispitane kože za izradu profesionalne obuće kreće se u granicama od 0,0813 do $0,0989 \mathrm{~m}^{2} \mathrm{C} / \mathrm{W}$; najveća razlika toplinskog otpora koža iznosi $21,6 \%$.

e) Pored debljine, i drugi parametri utječu na razinu toplinskog otpora koaža i tekstilnih laminata, najprije struktura kože i postupci njezine obrade i dorade.

f) Za potpuno definiranje razinu utjecaja svih relevantnih parametara koža na toplinski otpor, potrebno je poznavanje svih postupaka obrade i dorade koža sa recepturama, a što će biti obuhvaćeno u narednim istraživanjima.

g) Toplinski otpor kompozitnih laminata kreće se u granicama 0,0701 $\mathrm{m}^{2} \mathrm{C} / \mathrm{W}$ kod 4-slojnog kompozitnog laminata sa membranom za podstavu do $0,0918 \mathrm{~m}^{2} \mathrm{C} / \mathrm{W}$ kod 2-slojni tekstilni laminat za sare.

h) Za izradu profesionalne obuće koriste se različite vrste kompozititnih laminata a što ovisi o dijelu obuće za koji se laminati koriste i namjeni profesionalne obuće.

\section{Zahvala}

Ovaj rad je financirala Hrvatska zaklada za znanost projektom IP-2016-065278

\section{Literatura}

[1] Luximon A.: Handbook of footwear design and manufactue, Woodhead Publishing 2013., p. 300

[2] Mikulčić M., Kovačević S., Skenderi Z.: Materials for production of protective boots for workers in forestry Leather \& Footwer, 68 (2019), 1, 37-41.

[3] www.jelen.hr., pristupljeno 10.02.2020.

[4] Nishad Fathima N., M. Pradeep Kumar M., Raghava Rao J., Nair B.U.: A DSC investigation on the changes in pore structure of skin during leather processing, Thermochimica Acta Volume 501, Issues 1-2, 2010, Pages 98-102.

[5] Akalović J., Skenderi Z., Firšt Rogale S., Zdraveva E.: Water Vapor Permeability of Bovine Leather for Making Professional Footwear, Leather \& Footwear 67 (2018) 4, 12 17.

[5] Skenderi Z. Mijović B, Mihelić-Bogdanić A.: Thermophysiological wear comfort of footwear, Koža \& Obuća 66 (2017) 3, 12-21.

[6] A Kutnjak-Marvlinčić S., Akalović J., Bischof J.: Merging footwear design and functionality Autex Research Journal, DOI 10.2478/aut-2019-0023 @ AUTEX.

[7] Çolak S. M., Özdil N., Ekinci M., Kaplan Ö.: Thermophysiological Comfort Properties of the Leathers Processed with Different Tanning Agents, TEKSTiL ve KONFEKSIYON 26(4), 2016, 436-443.

[8] Hes L., Mihai A., Ursahe M.: Thermal insulation and thermal contact properties of upholstered leather furniture in wet state, Leather \& Footwear 67 (2018) 3, 13-17 [9] Kuklane K.: Protection of Feet in Cold Exposure, Industrial Health 47 (2009.) 3, 242-
253.

[10] Kuklane K. The Use of Footwear Insulation Values Measured on a Thermal Foot Model, International Journal of Occupational Safety and Ergonomics (JOSE) 10 (2004.)

[11] Irzmańska E.: The impact of different types of textile liners used in protective footwear on the subjective sensations of firefighters, Applied Ergonomics, Volume 47, March Pages 34-42.

[12] Skenderi Z. Mijović B, Mihelić-Bogdanić A.: Thermophysiological wear comfort of footwear, Koža \& Obuća 66 (2017) $3,12-21$.

[13] Koža -- Fizikalna i mehanička ispitivanja -- Određivanje debljine (ISO 2589:2016; EN ISO 2589:2016)

[14] HRN EN ISO 5084:2003. Tekstil -- Određivanje debljine tekstila i tekstilnih proizvoda (ISO 5084:1996; EN ISO 5084:1996)

[15] www.sensora.eu, pristupljeno 11.12.2019.

[16] ISO 11092 Standard "Textiles - Physiological effects - Measurement of the thermal and water vapour resistance 